DOI 10.37882/2500-3682.2021.08.02

\title{
ОСОБЕННОСТИ МЕЖЛИЧНОСТНЫХ ОТНОШЕНИЙ НА ОСНОВЕ СТЕРЕОТИПОВ МЕЖНАЦИОНАЛЬНОГО ВОСПРИЯТИЯ В СТУДЕНЧЕСКОЙ СРЕДЕ
}

\section{FEATURES OF INTERPERSONAL RELATIONS BASED ON STEREOTYPES OF INTERETHNIC PERCEPTION IN THE STUDENT ENVIRONMENT}

Yu. Buzykina

Summary: The article presents the results of a study of the features of interpersonal relations based on the stereotypes of interethnic perception in the student environment. Differences in the severity of altruistic, egoistic, subordinate and aggressive types of interpersonal relations were found among representatives of the Russian, Tajik, Kyrgyz and Turkmen nationalities. The stereotypes of interethnic perception in the student environment among representatives of neighboring countries are established.

Keywords: ethnic stereotypes, interpersonal relationships, psychological climate in the team, emotional and motivational orientations, representatives of neighboring countries, students.
На сегодняшний день изучение специфики межнациональных отношений является одной из наиболее актуальных проблем социальной психологии. Отношения между различными этническими группами выступают совокупностью некоторых социально-психологических явлений. Именно они характеризуют субъективное отражение многообразия связей, которые возникают между этносами, а также особенности взаимодействия этнических общностей $[8 ; 3]$.

Основные различия между этносами заключаются в особенностях традиций, национального сознания, культуры [2, с. 25], исторического прошлого того или иного народа. На характер межличностных и межгрупповых отношений могут существенно влиять социальные условия, в которых прибывает та или иная группа, и личностный опыт решения проблем, на основании которого формируется специфика взаимодействия с представителями своей и других этнических общностей [2, с. 25].

Существенную роль в межнациональных отношениях играет межгрупповое восприятие, для которого характерны такие динамические особенности, как [6]: устойчивость и консервативность, а также межгрупповые представления, которые через объединение индивидуальных представлений в единую картину, отличают-

\author{
Бузыкина Юлия Сергеевна \\ к.псх.н., дочент, ФГБОУВО «Пензенский \\ государственный университет» \\ ylamart@yandex.ru
}

Аннотация: В статье представлены результаты исследования особенностей межличностных отношений на основе стереотипов межнационального восприятия в студенческой среде. Обнаружены различия в выраженности альтруистического, эгоистического, подчиняемого и агрессивного типов межличностных отношений у представителей русской, таджикской, киргизской и туркменской национальностей. Установлены стереотипы межнационального восприятия в студенческой среде у представителей стран Ближнего зарубежья.

Ключевые слова: этнические стереотипы, межличностные отношения, психологический климат в коллективе, эмоционально-мотивационные ориентации, представители стран Ближнего зарубежья, студенты. ся от составляющих их элементов. Также межгрупповые представления могут складываться путем упрощения и схематизации восприятия других социальных групп, которые могут привести к образованию стереотипов.

Актуальность проблемы исследования особенностей межличностных отношений на основе стереотипов межнационального восприятия связана с недостаточной изученностью данных параметров в студенческой среде.

Студенческая среда, как специфическая социальная группа, имеет свои особенные условия жизни, отличается системой ценностных ориентаций и социальным поведением. В процессе общения между студентами разных национальностей формируются определенные интересы, потребности, раскрываются задатки и способности, расширяется круг познания, складывается межгрупповое взаимодействие, в рамках которого студенты различных этнических групп способны изменять свои сложившиеся представления, установки и превращать некоторые особенности в нечто общее.

Но, в тоже время, социальное сравнение и появление межгрупповой дифференциации может приводить к отдаленности от других этнических групп [7, с. 334-335] и формированию отношений соперничества. 
Стоит отметить, что на характер межгруппового взаимодействия также влияют и этнические стереотипы, которые в свою очередь играют основную роль при выборе тактики поведения с представителями той или иной этнической общности. В структуре стереотипа можно выделить несколько параметров [1, с. 51]: содержание (набор качеств, которые приписываются определенной этнической группе), однообразие качеств и оценок, приписываемых этнической общности, направленность (положительное или негативное восприятие объекта стереотипизации), интенсивность (степень предвзятости по отношению к стереотипизируемой этнической общности).

Теоретико-методологической основой исследования выступили работы зарубежных и отечественных ученых, занимающихся проблемой изучения этнической идентичности, межэтнических установок, стереотипов, межгрупповых отношений и межгруппового взаимодействия (Г.М. Андреева [1], А.С. Баронин [5], И.С. Кон, У. Липпман, Т. Лири, И.А. Савченко [9], Г.У. Солдатова, В.В. Старченко [10], Т.Г. Стефаненко [11], М. Sherif, Н. Tajfel и др.)

Полученные в ходе исследования результаты могут быть использованы в процессе планирования и проведения социально-психологических тренингов со студентами с целью профилактики межнациональных конфликтов различных этнических групп.

Эмпирическое исследование проводилось на базе ФГБОУ ВО «Пензенский государственный университет». В исследовании приняли участие 80 студентов различных национальностей в возрасте 19-24 лет.

В ходе исследования были использованы следующие диагностические методики: «Методика диагностики межличностных отношений» (Т. Лири) [4]; «Методика оценки психологической атмосферы в коллективе» (А.Ф. Фидлер); «Самооценка эмоционально-мотивационных ориентаций в межгрупповом взаимодействии» (Н.П. Фетискин); «Метод приписывания качеств» (Д. Кац, К. Брайль).

Полученные результаты были подвергнуты математико-статистической обработке данных с помощью критерия Н-Крускала-Уоллиса.

Установлено, что, не зависимо от этнической принадлежности, преобладают следующие стереотипы восприятия в студенческой среде:

- в отношении представителей киргизской и таджикской национальностей: дисциплинированность, адаптированность, гостеприимство, трудолюбие;

- в отношении русских студентов: патриотичность, уверенность в себе, целеустремленность, добро- та, дружелюбие, отзывчивость;

- для представителей туркменской национальности: гордость.

При этом такое качество, как оптимистичность, по мнению туркменов, характерно только для русских.

Кроме того, существуют следующие особенности проявления межличностных отношений на основе стереотипов межнационального восприятия в студенческой среде:

- выявлены значимые различия между представителями русской и таджикской $\left(\mathrm{h}_{\text {эмп. }}=9.5\right.$ при $\mathrm{p} \leq 0,01)$ национальностей по альтруистическому типу межличностных отношений, который в наибольшей степени характерен для таджиков. Это может выражаться в следующих качествах: деликатность, доброта, гостеприимство, отзывчивость, бескорыстие и сострадание. Такие люди чаще всего ориентируются на интересы других, стремятся помочь и сострадать всем, принимают на себя ответственность за происходящее. Представителям русской национальности, в основном, присущи следующие качества: осторожность, аккуратность, гордость, патриотичность, обладание чувством собственного достоинства, общительность, остроумие, дружелюбие, находчивость и уверенность в себе;

- выявлены различия между представителями русской и киргизской национальностей по эгоистическому типу межличностных отношений $\left(h_{\text {эмп }}=4.55\right.$ при $\left.\mathrm{p} \leq 0,05\right)$, который в наибольшей степени характерен для русских. На это могут указывать следующие качества русской молодежи: независимость, расчетливость, самовлюбленность и обладание чувством собственного достоинства, склонность перекладывать трудности на окружающих людей;

- выявлены различия между представителями таджикской и туркменской национальностей $\left(\mathrm{h}_{\text {эмп. }}=4.50\right.$ при $\left.\mathrm{p} \leq 0,05\right)$, а также киргизской и туркменской национальностей $\left(h_{\text {эмп. }}=5.04\right.$ при $\mathrm{p} \leq 0,05)$ по подчиняемому типу межличностных отношений. Так, подчиняемый тип межличностных отношений характерен для представителей таджикской и киргизской национальностей, что выражается в их скромности, уступчивости, покорности. Они стремятся к честному выполнению своих обязанностей, имеют склонность к подчинению более сильному лидеру. При этом, для представителей туркменской национальности характерны: доминантность, настойчивость, энергичность, компетентность, успешность в делах и уверенность в себе. Они руководствуются своим мнением, требуют уважения к себе и любят давать советы; 
- выявлены значимые различия в восприятии студентов таджикской национальности представителей киргизской и туркменской национальностей по агрессивному типу межличностных отношений $\left(\mathrm{h}_{\text {эмп. }}=7.01\right.$ при $\left.\mathrm{p} \leq 0,01\right)$, который наиболее выражен у туркменской молодежи. Так, по мнению таджикской молодежи, представители туркменской национальности обладают чувством собственного достоинства, гордостью, хитростью, высокомерием, вспыльчивостью, упрямством и настойчивостью.

Представителей киргизской национальности таджики видят, как дружелюбных, общительных, активных, гостеприимных и дипломатичных;

- значимых различий по эмоционально-мотивационным ориентациям в межгрупповом взаимодействии представителей русской, таджикской, киргизской и туркменской национальностей выявлено не было, что может говорить о схожем поведении во взаимоотношениях, которое ориентировано на сотрудничество, кооперацию и межгрупповую эмпатию;
- не выявлено значимых различий между представителями разных национальностей по оценке психологической атмосферы в коллективе. Это может говорить о преобладании благоприятного психологического климата общения между ними и о наличии в данных коллективах дружелюбия, сотрудничества и взаимной поддержки.

Таким образом, из полученных результатов видно, что существует специфика проявления межличностных отношений на основе стереотипов межнационального восприятия в студенческой среде.

Чем выше уровень сформированности позитивного стереотипа в восприятии представителей определенной национальности, тем благоприятнее психологический климат при взаимодействии с ними, а также тем выше уровень выраженности позитивных эмоционально-мотивационных ориентаций в межгрупповом взаимодействии.

Полученные результаты могут быть использованы при разработке рекомендаций, затрагивающих особенности межнациональных отношений представителей различных этнических групп.

1. Андреева Г.М. Социальная психология. - М.: Аспект Пресс, 2017. - 363 с.

2. Бузыкина Ю.С. Стереотипы межнационального восприятия студентов из стран Средней Азии // Социально-психологическая адаптация мигрантов в современном мире: материалы 5-й Международной научно-практической конференции / отв. ред. В.В. Константинов. - Москва: Изд-во «Перо», 2020. C. 25-29.

3. Бузыкина Ю.С., Позднякова А.М. Теоретический анализ особенностей межэтнического взаимодействия в студенческой среде // Социальные практики в информационном обществе: сб. науч. ст. по материалам науч.-практ. конф. «ХІХ Социологические чтения» / под ред. Т.И. Лавреновой. - Пенза: Изд-во ПГУ, 2020. - С. 126-130.

4. Диагностика межличностных отношений: методика Т. Лири // Практическая психология в тестах, или Как научиться понимать себя и других / сост. Р. Римская, С. Римский. - М.: АСТ-ПРЕСС, 2001. - 393 с.

5. Баронин А.С. Этнопсихология: учеб. пособие. - К.: МАУП, 2000. - 116 с.

6. Веревкин 0.Л. Стереотипы восприятия этнических групп // Мониторинг общественного мнения. - 2009. - №6 (94). - С. $193-207$.

7. Гулевич 0.А. Психология межгрупповых отношений. - М.: Московский психолого-социальный институт, 2007. - 432 с.

8. Завалишин А.Ю. Этнические стереотипы: экспликация и анализ // Журнал социологии и социальной антропологии. - 2017. - № 20(2). - С. 177-196.

9. Савченко И.А. Этнические стереотипы в студенческом сообществе // В мире научных открытий. - 2011. - Т. 15. - № 3(1). - С. 658-666.

10. Старченко В.В. Этнические стереотипы в межэтническом взаимодействии в поликультурном регионе // Наука и современность. - 2016. - № 49. C. $43-50$.

11. Стефаненко Т.Г. Этнопсихология: учебник для вузов. - М.: Аспект Пресс, 2009. - 368 с. 